\title{
COLLOQUiA
}

KAROLINA CZECH

Forum Pedagogiczne

University of Silesia

$2015 / 1$

Cieszyn (Poland)

\section{POLISH EVANGELICAL CHURCHES CONTRIBUTION TO BUILDING A CIVIL SOCIETY}

\begin{abstract}
The article contains considerations concerning a role of Churches and religion in building the civil society, bringing the readers closer to the specific movement in the history of Christianity which is evangelicalism and to Churches and communities that have grown out of this movement. The author concentrates mainly on Poland, pointing out that for Poles faith and Church membership is still a very important thing. In the article there are presented two examples of evangelical Churches, i.e., the Pentecostal Church in Poland and the Baptist Church in Poland; their interest in the common good and social engagement as well as their effort put into educating children to be responsible citizens has been underlined.
\end{abstract}

Key words: Church, religion, Christianity, evangelical Churches, civil society

\section{Introduction}

Traditional ethical order, Christian order, is now becoming in Europe a synonym for ignorance and backwardness. However, although at present Poland is being placed amongst countries that carry on a liberal and leftist discourse, belief and Church membership are still crucial elements of life for Poles (it is important to remember that generally a liberal attitude does not exclude a Christian attitude, nevertheless, for some, as Jan Kłos points out, comparing these two realities becomes a rock of offence) (Kłos 2014). The mentioned 'Church membership' means the Catholic Church membership in 93\% of cases (according to 2012 CBOS [Polish Survey Centre] data) (Boguszewski 2012) ${ }^{1}$, which leads to common, however false, conviction that a term $\mathrm{C} \mathrm{h} \mathrm{r} \mathrm{i} \mathrm{s} \mathrm{i}$ a $\mathrm{n}$ is identical to a term $\mathrm{c}$ a t h o l i c without taking other denominations into consideration. The same applies to a common use of a term $\mathrm{Church}$ in the sense of the $\mathrm{Catholic} \mathrm{Church}$ confining the definition of what a Church is.

Remaining $7 \%$, according to the above-mentioned data, constitute Protestants, orthodox Christians and other believers, as well as individuals declaring lack of religious denomination, atheism, agnosticism, and those hesitating or refusing to answer. For a significant

1 This data may slightly differ from the data collected in 2006 by 'The Gazeta Wyborcza' editorial board that conducted an extensive survey entitled 'Two Popes, two nations' according to which the Catholic Church membership is declared by nearly $90 \%$ of Poles. 
percentage of respondents deep belief is still something that plays the most important role in their lives (Boguszewski 2010). Thus, saying that belief and religion have a meaningful impact on Polish mentality as well as individuals' decisions, choices and lifestyles is not an exaggeration. Polish society cannot be assessed or analysed without taking Christian values, catholic tradition or a role of everyday religious rituals into consideration, as they constitute a national identity (even if it is only one of the aspects of a multidimensional identity). Churches are a part of Polish heritage, an inherent part of the society. Christian roots determine current ideal of a citizen, though it is vital to take into account many-sidedness of a term $\mathrm{Ch}$ ris t i a $\mathrm{n}$ it $\mathrm{y}$ which comprises varied currents and attitudes to social issues. At present one of these currents requires a deeper study as it is becoming an influencial over-denominational power that cannot be neglected, namely a protestant evangelical movement.

\section{A brief outline of the evangelical movement}

First, evangelical is not lutheran (in Polish language these two sound similar [ewangeliczny and ewangelicki] and are often mistaken) - these terms are not properly distinguished which might result from the fact that evangelical Churches followers account for rather a small percentage of Polish population against the numerical superiority of the Catholic Church. Nevertheless, the biggest Church out of the evangelical stream in Poland, namely the Pentecostal Church, is the third largest in the world, and what is more its legal status is regulated in a separate act. Reformation movements within the Catholic Church led to the formation of denominations constituting the stream called $\mathrm{p}$ r o t e s $\mathrm{t}$ a $\mathrm{n} \mathrm{t}$ in which, from the time of Sola Scriptura, Sola Fide, Sola Gratia, Solus Christus, Soli Deo Gloria, many revivals took place. One of such refreshing movements, pietist movement, growing out of Protestantism, was so-called evangelical Christianity ${ }^{2}$. Piotr Karaś in his dissertation underlines the fact that evangelical movement and social activity linked to it are not given enough attention in Poland, although it has a powerful inluence in the world, especially in the USA (Karaś 2013). Following Millard J. Ericson Karaś says: '[...] Evangelical Christians, per capita, have reached more in the social field than other Churches, even more than the whole American population' (Karaś 2013, p. 29). Disinterested social activity can surely be treated as a right attitude in a social society - attitude of concern and care about the common welfare.

Evangelicalism with its essence and roots is described by Tadeusz Zieliński as follows: 'Evangelicalism is a protestant movement emphasizing historical truths of faith determined by ancient ecumenical councils and 16th century reformers. Theological content of this message underlines the importance of the Bible as an ultimate authority in the issue of belief and Christian practice, meaningfulness of Christ's sacrifice made on the cross, necessity of personal acceptance of Christ's sacrifice through becoming aware of your own sins and, consequently, experiencing new life (conversion - metanoia) as well as a need for active, personal engagement of a believer in performing determined by the Bible religious

\footnotetext{
2 Zbigniew Pasek writes that apart from pietism that developed in lutheran countries other movements evolved. These were puritanism in England or the Mennonites and Baptists in the Netherlands. The movements were a response of Protestants for the stagnation in lutheran Churches (Pasek 2004).
} 
and s o c i a l duties' (Zieliński 1995, p. 240). Mentioned 'social engagement' that grows out of an attitude of obedience to God becomes an essential element in deliberations about evangelical Churches' role in building a civil society.

The XVIIth century pietism³, German pietism, or a little later British methodism ${ }^{4}$, laid the grounds for so-called Holiness Movement which in turn became the cornerstone for a great deal of evangelical Christian organizations and religious communities. It is vital to remember that evangelical movement is a specific type of piety and embraces different Churches, it has an overdenominational character; there can be either 'evangelical Protestants' or 'evangelical Catholics'.

Poland too witnessed revival's repercussions. An interesting picture of revival and identity's transformations in Polish religious communities (mainly protestant) is presented in the issue published on the occasion of the 1ooth anniversary of the Związek Stanowczych Chrześcijan (protestant religious community founded at the beginning of the XXth century in Cieszyn Silesia - a historical region in the south of Poland - which was one of the breakthroughs towards evangelicalism). Admittedly, the publication shows only a part of the whole process of transformation, that is situation in Cieszyn Silesia, but it can been seen how the changes happened - through individuals that themselves experienced new sensations and witnessed effectively to others. However, if the ground had not been suitable, the changes would have not happened. Individuals that underwent special Holy Spirits' touch (speaking in tounges, glosolalia, became a symptom of the Holy Spirits' doing) were mostly removed from the Churches' records, and next established new fellowships building foundation of present evangelical organizations and communities. A complete, to some extent somehow, picture of evangelical communites can be found in a catalogue of Polish Churches associated in Evangelical Association of Poland. In 2004 there were about 70 evangelical Churches and communities registered in Poland (out of 160 other Churches and religious communities) (Pasek 2004).

Noemi Modnicka describes Polish evangelical communities as 'Churches of choice' (Modnicka 2004, pp. 73-74.). This means that most of the Polish evangelical communities constitute 'the converted'. She further explains what the conversion is, namely a profound, radical change of identity that could be called a new self-identification. The conversion is a constitutive element of the idea of evangelical philosophy.

${ }^{3}$ According to the definition given in the publication issued on the 1ooth anniversary of the Związek Stanowczych Chrześcijan [one of the protestant associations] 'p i e t i s m was a movement that stressed individual religious experience and required from a man a life in which their deeds were in accordance with beliefs. The movement developed philantrophic and charitable activity [...]. Pietists were one of the initiators of religious education for children. From a mature Christian an experience of a spiritual turning point, called by Paul the Apostl a new birth or conversion, was expected' (Bubik, Michnik, Śliż, Wigłasz, 2010, p. 14).

4 Wesley's methodism was inspired by pietism. A. Simieniewski in his Ewangelikalna duchowość nowego narodzenia a tradycja katolicka, links an inception of methodism to an evangelical spiritual movement in Anglo-Saxon world (Siemieniawski 2010). 


\section{What a civil society is and what role evangelical Churches and communities play in it}

Belief is linked to an idea of freedom understood as being free from outer factors (such as a state, which comprises obligation and violence, as well as physical and individualistic impossibilities). It becomes an inner, mental freedom (as a Kant's postulate of pure reason enabling us to acknowledge ourselves as free individuals, which is an essential condition of rational predicating about the reality ${ }^{5}$ ), it also becomes a choice of an individual and an expression of latitude in decision making. Mind is not easily enslaved by outer preassure, sometimes it becomes the only and the last bastion of independence. Of course, lack of constraints imposed by persons, groups or institutions make it much easier to celebrate belief and rituals or to manifest own religion, and consequently leads to relative comfort of an individual whose personality is integrated - principles and truth which they believe in can be publicly implemented. What enables an individual to openly proclaim is (at least it is assumed so) democracy, which, regardless of restrictions and dangers it entails, is thought to be inseparately linked to a notion of the c iv il s o ciet y, understood as a zone of free, self-governing, nondirective activity of individuals, groups and institutions ${ }^{6}$.

It is commonly believed that weakness of Polish democracy, and the civil society at the same time, is deficiency of social capital ${ }^{7}$, which in consequence results in the fact that discussed civil society is built not on the foundation of positive values and activity but on the foundation of criticism of reality and attempts of repairs ${ }^{8}$. Bronislaw Geremek points out that sources of a notion of the civil society in Poland date back to communist times when a specific intellectual resistance movement against oppressive system arose. Organisation and programme of this movement opposed the state (Geremek mentions here army, police and political administration as elements that alienate and are deprived of legitimization), which resulted in the fact that a forming civil society was power characterised by negative values (Geremek 1994). Thus, nowadays, it seems cruicial to allow positive elements to play a greater role in building the civil society and allow individuals, groups and institutions to inhibit a state's paternalistic inclinations through natural, resulting from firm interpersonal relations, mutual trust and believe in causative power and activity.

A role of religion and Churches in building the civil society as well as educating for it seems obvious. Professional literature shows different authors' approaches to the issue which, nonetheless, have one common standpoint, namely of Churches and religion's capability to socially integrate through indicating aims and good examples of bahaviour in

${ }^{5}$ A subject of freedom is discussed by A. McCoy in: Przewodnik dla inteligentnych. Etyka chrześcijańska. (McCoy 2007)

6 R. Darendorf lists political parties, trade unions, industrials corporations, social movements, freelancing, autonomous universities, independent Churches and foundations as organs of the will of the people (Darendorf 1994).

7 Anita Miszalska pays attention to this in her article entitled 'Sytuacja demokracji u chyłku wieku; niepokoje globalne, niepokoje polskie' (Miszalska 200o).

${ }^{8} \mathrm{~A}$ thesis about a civil disobedience as a motive for contemporary societies to league is developed, on the basis of Michael Walzer's considerations referring to morality based on good (which is one of the two kinds of morality) as a civil activity trigger, by Edyta Pietrzak in the article entitled 'Nieposłuszeństwo i profanacje - globalne społeczeństwo obywatelskie' (Pietrzak 2013). 
the socialization process of an individual (Kuczur 2008). Moreover, believers and Churchgoers are thought to be more active in the social fields (Mariański 2003). Churches and democratic civil societies do not have to compete. Christian Churches involvement could lie in making endeavours towards a minimal moral consensus needed for democracy, nevertheless one may ask a question about what makes Christian truth and values superior to others. Edward Shils, in his What is a civil society, underlines that the sacred is almost always hidden in a language - we refer to certain sources of legal force (Shils exemplifies it with such terms as 'natural justice', 'honesty', etc.). Further, he claims that there is need for the idea of a higher law, standard or criterion of what is right or good, and what should be individuals and groups' goal pursuit in the civil society (Shils 1994). Thus, if we assume that the sacred sphere is an element constituting society, we need to accept the fact that in European countries, including Poland, resulting from history and tradition superiority of Christianity is quite obvious. Christianity is a religion of peace, and, although there have been evil deeds done in God's name, the Bible never calls people to do evil but encourages to respect governements, love others as yourself, and many other positive behaviours.

As soon as we agree to the assumption that determinants of the civil society are two basic elements, namely active participation in the social life and, following Shils, collective self-consciousness characterized by interest in the common welfare, and if we agree that Churches may play a role in the process of building such society, it is high time to ask a question about the way in which evangelical Churches can contribute to it. What is their approach to social issues or individual civil responsibility to the whole society? In what way do they constitute the civil society and do they raise children in the spirit of its ideological foundation?

Let us first consider what the changes, brought by evangelical movement, were about. How did Christians mentality change and what new outlook on social issues did Churches acquire? Primarily, it is necessary to go back to the period when protestant ideas for the first time left their mark; had it not been for Luther, nowadays evangelical communities would not exist. The author of the herewith article takes a risk to express an opinion that a present level of spirituality distinctive for mentioned communities is nothing more than a specific, highest, however we do not know if the ultimate, stage in history of development of the Christian religion - they (communities) have evolved from the Roman Catholic Church to a present form (through reform and revival movements). On the other hand, however, it can be as well assumed that evangelical communities go back, in their form, to original, pre-institutional Church described in the Bible and to experiencing the same sensations that were shared by very first Christians (e.g. baptism in the Holy Spirit).

It is known that a different approach to economic issues, and to capitalism in general, has become one of the basic distinguishing mark between protestantism and catholicism (Weber 1994). Other elements differentiating both branches of Christianity are, first, source of cognition - for Catholics it will be Holy Scripture as well as Tradition, for Protestants sola scriptura is the ultimate point of reference (at least the latter is prior); second - a problem of intercession between a man and God, where for Protestants it is only a person of Jesus Christ. Evangelical communities have contributed to these changes a belief in personal relation with Jesus Christ, ultimate recognition of the Bible as the highest authority in every single issue and last but not least, the above-mentioned specific kind of spirituality in which a necessity of experiencing metanoia by an individual is underlined. In reference to 
an approach of evangelical Churches to social issues, the literature ${ }^{9}$ tells us about William Wilberforce as a pioneer of the social engagement within the evangelical movement. He was a member of a Christian group called Clapham Sect which emphasized a necessity of belief connected to practice; preaching the gospel was supposed to be not only through individual testimony but also through charitable deeds. Extracts from the Holy Scripture saying that, i.a., belief without deeds is dead and that orphans, the poor, the sick and those leaving prisons should be cared about, have become an obliging command for evangelical Christians around the whole world.

Karaś points out that international evangelical congresses in 6os and 7os of the 2oth century were crucial for social engagement of the Evangelicals (Karaś 2013). He mentions the Congress of World Evangelism that was held in Berlin where 'evangelism was pushed into a new direction, into a new dimension' (Karaś 2013 p. 42) and it was acknowledged that evangelical environments could not be fundamentalist enclaves anymore but they had to turn to the world and take responsibility for the society. Another crucial event was the Congress of World Evangelism in Lausanne in 1997 followed by the so-called Lausanne Covenant. Article no 5 of the Covenant says: 'We declare that God is both Creator and Judge of all people and that is the reason why we should be interested in justice in the human society. As each man has been created in the image of God, they should be treated with highest reverence regardless of race, religion, skin colour, social class, sex or age, and they should be served not exploited. We also confess our fault because of both negligence and treating evangelism and social care as mutually exclusive elements. Reconciliation amongst people is not reconciliation with God, social activity is not evangelism and political freedom does not mean salvation; nevertheless, we claim that both social activity and evangelism are necessary manifestation of our teaching in relation to God and mankind as well as of our duty to love other people. Teaching on salvation implies also teaching on judgement over alienation and oppression. When an individual accepts Christ, they are born again for His Kingdom and are obliged to manifest His righteousness in the unrighteous world' (Czajko, Kwiecień, Tomaszewski 1981, pp.365-372). Significance of these events meant that all evangelical subjects meeting social problems, that is Churches, foundations, associations, started from this time to become conscious participants of the p r o c e s s of forming the civil society. We are talking about 'process' as, let us follow Tomasz Kuczur, 'collapse of an undemocratic system does not entail automatically development of civility'(Kuczur 2008, p. 157) - b u i l d i n g the civil society as well a s e d u c a t i $\mathrm{g}$ for it require certain, responsible activities rooted in ideological foundation. There is huge social potential in evangelical Churches, deep-seated in religious beliefs, carrying a plenty of positive values and virtues, being a heritage of past generations and transformations in the bosom of Churches, such as puritan diligence, honesty, dutifulness, responsibility, and other, constituting capital that can be used for public welfare (Karaś 2013). This requires primarily creation of proper communication channels with existing subjects of local community.

The already mentioned role of religion and Churches in social integrating through setting goals and right behavioural patterns in the process of an individual's socialization is expressed, in case of evangelical Churches, in the bring ing up and moulding

9 Here i.a. D. J. Tidball'a and his Who are evangelicals? (Tidball 1994), or J. Stalker and his Evangelicalism (Stalker 1955) should be mentioned. 
a child's attitudes education, that is in social teaching (although it is not a separated category), general teaching as well as Sunday school teaching (shaping children and teenagers' attitudes). Contribution of evangelical Churches and communities to building the civil society is expressed through:

1. creating connection networks and at the same time building social capital,

2. creating aid institutions guided by biblical norms and laws, which is the basis for independent development of followers and is the expression of their activity (and it has been agreed that this is one of the determinants of the civil society),

3. promoting attitudes of a good citizen - honest, responsible, interested in the common weal,

4. responding to marginalization through shaping attitudes of sensitivity to other people's problems as well as bringing individuals back to society (social re-adaptation of the addicted, the convicted, the homeless, etc.); at the same time their social functionality is being restored.

Let us now look at the ideological declarations of two example evangelical Churches. The biggest Church in Poland in a discussed category is the Kościół Zielonoświątkowy (the Pentecostal Church), which was founded on the ground of mentioned Holiness Movement. The presbyter of the Pentecostal Church in Poland, bishop Marek Kamiński, in his historical and political study entitled 'The Pentecostal Church in Poland in 1988-2008' points out the significance of the following determinants that led to the formation of pentecostal movement (Kamiński 2012):

1. dynamic developement of theology promoting mystic experiences and acceptance for extraordinary manifestations of Holy Spirit and charisms,

2. intensive and influential activity of preachers connected with Holiness Movement,

3. formation of certain social customs amongst followers, namely popularity of regularly organized revival camp meetings where the most important topic of preaching was Holy Spirit and their working,

4. popularity of Bible schools in which issues relating to waiting for so called outpouring of Holy Spirit were particularly discussed.

The Pentecostal Church in Poland has a developed network of organizations that aim at charity. Followers, through social activity within pentecostal aid institutions, express their faith and biblical vision of a human with their role in the society. It is taken for granted that the followers are not politically - driven but what motivates them is this universal vision of a man as the highest value. It is important for them to live in harmony with the society, to give an example of a right attitude to life, and, what is most vital, to reconcile people they work with with God.

The internal regulations of the Pentecostal Church in Poland ${ }^{10}$ indicate that the legal status of the Church is regulated by the 2oth February 1997 Act on the relation between the state and the Pentecostal Church as well as the 17 th May 1989 Act on the right to freedom of conscience. In the Pentecostal Church regulations can also be found the information that, first, the primary purpose of the Church is preaching the Gospel and making people Christ's followers; second, that according to its doctrine the Church aims at the reduction

10 All regulations concerning the Pentecostal Church in Poland as well as reports on current performance are available for a reader on the Church's official website: www.kz.pl. 
of negative aspects of both interpersonal relations and a social life, particularly such as: social marginalization, poverty, homelessness, addictions, demoralization and criminality. The Church realizes its goals through i.a. educational and pedagogical activity, establishing organizations for the benefit of religious formation, public cult and counteracting social pathology and its effects, running public benefit organizations as well as charity and caring organizations, performing ministry in prisons, hospitals and armies, running social clubs, organizing and conducting sports and recreational actions. It can be concluded from the Church's declarations that there is willingness to initiate and to join inter-church organizations as well as international denominational organizations in order to accomplish set tasks. Evangelical Churches together with their network of relations have a hidden powerful potential, such is their capability to perform a normative functions. What is more, they are certainly expected to participate in a dialogue on a moral minimum which guarantees individuals' rights in a democratic society are kept. Agreement to a basic set of values which would constitute a core of educational and pedagogic programs executed consistently by educators, carers and teachers should be a subject of the greatest concern. The Pentecostal Churches, and not only them, are aimed at Christian education of children and youth, shaping an attitude of reverence towards another man, an unselfish attitude of awareness of problems seen around, an attitude of interest in improvement of standards of living through engagement in different kinds of organizations setting such goals. Teaching of the Pentecostal Church definitely concentrates on not being indifferent, which is considered to be one of the basic aspects of the civil society; an examplary item 2 of the 25 th article of the 7 th chapter of the Pentecostal Church internal law proves this best. Other words, Pentecostals set themselves high ethical standards and try to realise them practically.

Summing up reflections concerning the Pentecostal Church, a former bishop of the Church's words will have to be quoted. Mieczysław Czajko says: '[...] the Pentecostal Church's image is not being created on the grounds of its care for 'prayer and ministry for the sake of Scripture' (using the Acts of the Apostles' language) but on the grounds of social and charitable actions. We consciously go into this direction too [...]. However, and now the latest example, if we run a youth club and its head becomes a person deserved for the town we are simply happy about this as it builds a positive picture of the church too. The positive tendency will be becoming established as we are part of the movement that holds the second place in the Christian world. Ignorance must vanish!'(Kwiecien 2003, p. 17).

Another example of a big free protestant Church of evangelical nature is Kościól Chrześcijan Baptystów (the Baptist Church) in Poland organizing Polish Baptists. It is a member of above mentioned Evangelical Alliance in Poland and functions on the grounds of the Act on the relation between the state and the Baptist Church in Poland. The official website of the Baptist Church in Poland tells us that the origins of the Polish baptist movement date back to middle 19th century when in Adamow near Warsaw a group of the Bible readers spontaneously decided to get baptized as an expression of confession of faith and establish a Church of conscious believers modelled on the New Testament (Zieliński 2014).

The character of teaching and the Baptist Church doctrines result from protestant achievements. Its origins are in English puritanism and firm rejection of infant baptism is a conclusive distinguishing mark that separates Baptists from the so called 'purely 
protestant' Churches. It must be added, however, that not all Baptists can be described as evangelical Christians (Zieliński 2001).

Baptists accept the autonomy of individual communities, they often differ as far as certain issues are concerned, nevertheless, they share a characteristic outlook on social matters. In what way can the Baptist Church be viewed as a participant of a process of building the civil society? To some extent for the same reasons as other evangelical Churches. Baptist Churches, at least those of an evangelical character, have grown out of the same ideological assumptions as other discussed communities. They too want their Christianity to be practical, which is expressed through individual Churches' regulations. These regulations indicate that the Baptist Churches have a right to act in the field of charity and also establish schools, nurseries, educational institutions, hospitals or others. Baptists are driven by the God's imperative to be His witnesses and to implement His word in life i.a. through social engagement.

A good example of the importance of the Bible as the highest authority is what happened on 31st October 2013, at the anniversary of the Reformation. The Baptist Church in Poland decided to send New Testaments and Psalms to politicians and representatives of the biggest media to indicate the timeless truths hidden in the Bible that had a significant influence on the process of forming present capitalism, freedom of conscience and political systems based on the principle of co-participation of the society in ruling the state as well as on promoting civil attitudes. The chairman of the Baptist Church in Poland, Mateusz Wichary, $\mathrm{PhD}$, expresses the opinion that the Bible is our common good that should be cared for.

The intelectual and spiritual incentives for the development of both the Baptist Church and other evangelical Churches and communities came, at least in the beginning, from abroad. The charity and mission activity of these Churches was too well-developed in those countries. When evangelical revivals came to Poland, the need for sharing the individual spiritual experience with others came too. People started to league and engage in helping people locally, as it was the expression of their faith and loyalty to God's Word. Włodzimierz Tasak underlines that such natural process of hoarding applied to the first Polish Baptists too (Tasak 2007). Together with Baptists came spontaneous activity that entailed the foundation of educational centres and intensive deacon ministry. It is highlighted in the Baptist Church ideological foundation that God's Word penetrates not only the religious realm of a man but also intelectual and existential (Zieliński 2007), which is the reason why the deacon ministries have always been one of the top priorities for Baptists. And the ministries are addressed not only to co-believers but also to people from outside the Church. Baptists are as well known for language schools, youth camps and other activities concerning young people where positive values and attitudes are propagated. In this sense the Baptist Church becomes a valuable asset to the Polish society with their genuine interest and concern for the common good, it too becomes an equal partner in the social dialogue.

From the present article's point of view it is important that a special attention is paid to the following words which are the expression of a baptistic idea of a man and their role in the society: 'Faith of an individual who trusted Jesus should permeate whole their life and not be just a decorative element. It becomes inspiration for intelectual and emotional developement or creative activity for the environment. It puts a heart at rest, brings joy of existance and endurance in difficult times. Redeemed persons find, thanks to Holy 
Spirit, capability to break habits or practices unworthy of a Christian. They also cultivate a family and social life, respect dignity and sanctity of a marriage as well as give priority to a role of a family as the most basic social institute. They give special importance to a careful education and upbringing of children and youth. A believer tries to give a good example through conscientousness at work or responsible position in the life of a state and implements their commitments to secular authorities duly'(Zieliński 2007, p.4). And let this quotation be a summary of the deliberations about Baptists.

\section{Summing-up}

Can evangelical Churches and communities function in reality without losing their identity? Do secular societies, including Polish one, need Churches' preaching? Their moral doctrine becomes a source of confict in particularly sensitive topics, such as life prevention or homosexuality. Yet, society have always needed religion, metaphysics or, generally speaking, a benchmark. There is a belief shared by evangelical Churches and communities' leaders that democratic climate is advantegeous for the Church followers as it enables to present the willing this specific offer which is the Gospel. However, to make the offer authentic and attractive for individuals it must be reinforced by practice, by visual fruits in its heralds lives. That is the purpose which social and civil activity as well as personal testimony serve. Acting expresses a deep belief in proclaimed mottos and at the same time the essence of Christianity - serving others, being interested in others' good as well as binding stable and based-on-trust relationships. Thus, discussed communities can be called 'Churches in action'. And is not it the gist of the civil society? Stephan Raabe in his 'Transformacja i społeczeństwo obywatelskie w Polsce. Kościól jako sojusznik społeczeństwa obywatelskiego' (Raabe 2008) points out that the civil society is the organ that cannot be created by the state through enforcement measures or through the economy based on competition. Its development is stimulated from one side by outer force which is the intensity of the political and economic transformations, and, from another side, by inner force which is the ethical attitude of those who want to contribute to the society and the common good. At this point we clearly see the role of evangelical Churches - the Church is the people, and the people in the evangelical communities are particulary characterized by profound and resulting from the conversion attitude of love and care towards others.

Let us now summarize the most important attributes of the evangelical Churches that make us treat them as serious co-participants:

1. Evangelical communities take part in building the civil society on the foundation of positive values and activity and not on the foundation of criticism

2. They have a natural capability to integrate people and promote good attitudes, which is the expression of what they believe in

3. They participate in the discussion over a minimal moral consensus as well as promote examples of ethical behaviour

4. They serve the ideological foundation for activities towards building the civil society

5. Their deep-seated in religious beliefs social potential acts as a capital that co-builds the social networks

6. They pay special attention to bringing up and teaching children to be independent, aware and concerned about others individuals 
7. The pursuit of peace and mutual respect lies in evangelical new born nature.

To show the future prospects for the evangelical communities contribution to the civil society some of the incentives listed by Zieliński will be raised (Zieliński 2004). First, the Gospel they preach, which is purely based on the Bible alone and which gives hope to a man to help them in their everyday life struggles as well as frees them from the sin. Zieliński underlines the fact that the evangelical message is, unlike the traditional ludic religiousness, not based on fright and martyrdom. Such vision of Christianity makes it more attractive for people and becomes an answer for those seeking more spirituality in life and those who want to escape from the materialism of the present world. Second - everyday individual devotion which gives a man more than holiday rituals and makes Evangelicals not only declare the faith but $\mathrm{p} \mathrm{r}$ a $\mathrm{ct}$ i s e it in their lives. This in turn results in 'work ethic, thriftiness, honesty, straightforwardness, clean hands as well as respect for pluralism, protection of the weakest and the state as the common good' (Zieliński 2004, p. 139). Such values are needed now and in the future. Another incentive is a sense of initiative and entrepreneurship that have always made Evangelicals feel independent from religious institutions and pushed them towards innumerable missions as well as educational, charitable and political and social projects. The future strength of the state lies, i.a., in the well-developed civil society which will be built thanks to such free activities and by free people.

Evangelical, or wider - Christian, outlook on individual responsibility of a person for their life and environment around assumes that we have received free will from God and, at the same time, a right to choose the way to follow. The Bible sets norms of conduct distinguishing clearly between good and evil and leaves a choice to a man. It means that the Bible can play a normative role and in the well-understood civil society there is a great need for indications which the Bible could provide as the society itself is not able to supply such.

\section{References}

Boguszewski R. (2010). Co jest ważne, co można, a czego nie wolno - normy i wartości $w \dot{z} y c i u$ Polaków, available from: http://www.cbos.pl/SPISKOM.POL/2010/K_099_10. PDF (accessed: 14.01.2015).

Bubik P., Michnik A., Śliż J., Wigłasz Cz. (eds.). (2010). 10o-lecie Związku Stanowczych Chrześcijan. Cieszyn: Wydawnictwo Arka.

Darendorf R. (1994). Zagrożone społeczeństwo obywatelskie. In: Król M.,Smolar A. (eds.). Europa i społeczeństwo obywatelskie. Rozmowy w Castel Gandolfo. Kraków: Wydawnictwo Znak.

Geremek B. (1994). Społeczeństwo obywatelskie i współczesność. In: Król M.,Smolar A. (eds.). Europa i społeczeństwo obywatelskie. Rozmowy w Castel Gandolfo. Kraków: Wydawnictwo Znak.

'Gazeta Wyborcza' (2006), no. 122, p. 8.

Kamiński M. (2012). Kościół Zielonoświątkowy w Polsce w latach 1988 - 2008. Warszawa: Wydawnictwo Arka.

Karaś P. (2013). Działalność socjalna kościołów ewangelikalnych w Polsce. Warszawa: Wyższa Szkoła Teologiczno-Społeczna w Warszawie. 
Kłos J. (2004). Liberalizm i chrześcijaństwo - dwa spojrzenia na wolność. In: Kaute W. (ed.). Demokracja, liberalizm, społeczeństwo obywatelskie. Doktryna i myśl polityczna. Katowice: Wydawnictwo Uniwersytetu Śląskiego.

Kuczur t. (2008). Ethnos i polities. Naród a społeczeństwo obywatelskie we współczesnej Europie. Toruń: Wydawnictwo Adam Marszałek.

Kwiecień M. (2003). Niewiedza musi znikać. 'Chrześcijanin', no. 7-8, p. 17.

Mariański J. (2003). Kościót katolicki a rozwój społeczeństwa obywatelskiego. 'Rocznik Lubuski' vol. XXIX, part 1, p. 115.

McCoy A. (2007). Przewodnik dla inteligentnych. Etyka chrześcijańska. Poznań: Wydawnictwo Polskiej Prowincji Dominikanów 'W drodze'.

Miszalska A. (200o). Sytuacja demokracji u schytku wieku; niepokoje globalne, niepokoje polskie. 'Kultura i Społeczeństwo', no. 3, pp. 23-46.

Modnicka N. (2004). Polskie społeczności ewangelikalne jako 'Kościoły wyboru' w 'społeczeństwie losu'. In: Zieliński t. J. (ed.). Ewangelikalny protestantyzm u progu XXI wieku. Warszawa-Katowice: Wydawnictwo Credo.

Pasek Z. (2004). Różnicowanie się ewangelikalnego protestantyzmu w Polsce 1989-2003. In: Zieliński t. J. (ed.). Ewangelikalizm polski u progu XXI wieku. Warszawa-Katowice: Wydawnictwo Credo.

Pasek Z. (2004). Topika zbawienia w polskich kancjonałach ewangelikalnego protestantyzmu. Kraków: Wydawnictwo Uniwersytetu Jagiellońskiego.

Pietrzak E. (2013). Niepostuszeństwo i profanacje - globalne społeczeństwo obywatelskie. 'Przegląd politologiczny', no. 1, p. 89.

Przymierze Lozańskie, trans. J. Tołwiński. In: Czajko E., Kwiecień M., Tomaszewski H.R. (eds.) (1981). Kalendarz Chrześcijanina 1981. Warszawa: ZKE.

Raabe S. (2008). Transformacja i społeczeństwo obywatelskie w Polsce. Kościół jako sojusznik społeczeństwa obywatelskiego. 'Raporty Fundacji Konrada Adenauera', no. 9, p. 5.

Shils E. (1994). Co to jest społeczeństwo obywatelskie? In: Król M., A. Smolar (eds.). Europa i społeczeństwo obywatelskie. Rozmowy w Castel Gandolfo. Kraków: Wydawnictwo Znak.

Siemieniewski A. H. (1997). Ewangelikalna duchowość nowego narodzenia a Tradycja katolicka. Wrocław: Papieski Fakultet Teologiczny.

Stalker J. (1955). Evangelicalism. In: Hastings J. (ed.). Encyclopedia of religion and ethics. New York - Edinburgh: T\&T Clark.

Tidball D. J. (1994). Who are evangelicals? Tracing the roots of the modern movements. London: Marshall Pickering.

Weber M. (1994). Etyka protestancka a duch kapitalizmu. Lublin: Wydawnictwo Test.

www.kz.pl (accessed: 14.01.2015).

www.baptysci.pl (accessed 14.01.2015).

Tasak W. (2007), Poczatki ruchu baptystycznego na ziemiach polskich, available from: http:// www.baptysci.pl/kosciol/944-poczatki-ruchu-baptystycznego-na-ziemiach-polskich (accessed: 14.01.2015).

Zieliński t. J. (2007), Kościół Baptystyczny: historia, doktryna i organizacja, available from: www.baptysci.pl/kosciol/943-kosciol-baptystyczny-historia-doktryna-i-organizacja?start=1 (accessed: 25.07.2014).

Zieliński t. J. (2001). Ewangelikalizm. In: Gadacz T., Milerski B. (eds.). Religia. Encyklopedia. Warszawa: PWN. 
Zieliński t. J. (2014). Protestantyzm ewangelikalny. Katowice: Wydawnictwo Credo.

Zieliński t. J. (1995). Purytanizm. Zarys dziejów, ideologii i obyczajów anglosaskiego ruchu reformacyjnego. 'Rocznik Teologiczny ChAT', no. 37, vol. 2, p. 240.

Zieliński t. J. (2004). Hamulce i podniety rozwoju ewangelikalizmu polskiego u progu XXI stulecia. Studium $w$ profilu teologiczno-systematycznym. In: Zieliński t. J. (ed.). Ewangelikalny protestantyzm $w$ Polsce u progu XXI wieku. Warszawa-Katowice: Wydawnictwo Credo.

\section{UDZIAŁ POLSKICH KOŚCIOŁÓW EWANGELIKALNYCH W BUDOWANIU SPOŁECZEŃSTWA OBYWATELSKIEGO}

Streszczenie: Artykuł zawiera rozważania dotyczące roli Kościołów i religii w budowaniu społeczeństwa obywatelskiego, przybliżając czytelnikowi szczególny nurt w historii chrześcijaństwa, jakim jest nurt ewangelikalny oraz powstałe na jego gruncie Kościoły i wspólnoty wyznaniowe. Autorka skupia się przede wszystkim na Polsce, ukazując, że wiara i przynależność do Kościoła jest dla Polaków wciąż sprawą nader istotną. W artykule zaprezentowane zostały dwa przykładowe Kościoły nurtu ewangelikalnego: Kościół Zielonoświątkowy i Kościół Chrześcijan Baptystów. Podkreślono ich zainteresowanie wspólnym dobrem, zaangażowanie społeczne, jak również wysiłek wkładany w wychowanie dzieci na odpowiedzialnych obywateli.

Słowa kluczowe: Kościół, religia, chrześcijaństwo, Kościoły ewangelikalne, społeczeństwo obywatelskie

Karolina Czech - licencjat pedagogiki, nauczyciel z ponad 1o-letnim doświadczeniem zawodowym, studentka na Wydziale Etnologii i Nauk o Edukacji Uniwersytetu Śląskiego w Cieszynie, stypendystka ministra w roku 2014. Adres do korespondencji: Karolina Czech, ul. Srebrna 18/2, 43-40o Cieszyn. E-Mail: czech.carla@gmail.com. 